\title{
Periphyton communities in experimental marine ecosystems: scaling the effects of removal from container walls
}

\author{
Chung-Chi Chen ${ }^{1,2}$, W. Michael Kemp ${ }^{1, *}$ \\ ${ }^{1}$ University of Maryland Center for Environmental Science, Horn Point Laboratory, PO Box 775, Cambridge, \\ Maryland 21613, USA \\ ${ }^{2}$ National Taiwan Normal University, Department of Life Sciences, Taipei, Taiwan 116, ROC
}

\begin{abstract}
Although it is widely held that growth of periphyton communities on walls of marine mesocosms creates artifacts which bias experimental results, there are surprisingly few studies that directly quantify such 'wall effects'. To test the hypotheses that the magnitude of wall effects is related to experimental system dimensions and that these effects can be controlled by routine periphyton removal, we conducted a series of studies using cylindrical mesocosms of 5 different sizes and shapes with treatments involving removal of wall periphyton. Results indicate that periphyton biomass and production were consistently and significantly reduced in containers receiving twiceweekly wall-cleaning treatment, but not in systems cleaned at weekly intervals. Whereas partitioning of ecosystem properties (total primary production and algal biomass) among wall, plankton, and sediment habitats revealed large and significant changes with wall-cleaning, treatment effects on the mean values of these and other ecosystem-level properties (e.g. nutrient concentrations) were small to negligible and generally inconsistent. Changes in biomass of wall periphyton and phytoplankton induced by wall-cleaning were significantly related to mesocosm radius. Reductions in wall periphyton with cleaning treatment were generally compensated by parallel increases in algal biomass in other habitats, with enhanced sediment microalgae only present in shallower systems. It appears that wall-cleaning also affected the abundance of benthic macrofauna and bacterioplankton, as well as phytoplankton taxonomic composition. Although periphyton dislodged through wall-cleaning were retained within the mesocosms in this study, we estimate that removal of this material from the experimental systems would have caused a severe nitrogen loss, equivalent to that required for supporting total ecosystem primary production.
\end{abstract}

KEY WORDS: Mesocosms $\cdot$ Experimental ecosystems $\cdot$ Scale $\cdot$ Wall-cleaning $\cdot$ Periphyton $\cdot$ Phytoplankton $\cdot$ Gross primary production $\cdot$ Sediment microalgae $\cdot$ Nutrients

\section{INTRODUCTION}

Experimental ecosystems are basic and versatile tools commonly used in marine research (Giesy 1980, Grice \& Reeve 1982, Lalli 1990, Beyers \& Odum 1993). Although a wide range of sizes and shapes has been used, most of these experimental systems (referred to here as 'mesocosms') are relatively small $\left(\leq 1 \mathrm{~m}^{3}\right)$ in size (e.g. Petersen et al. 1999). Mesocosms have been used to investigate diverse research topics including: trophic interactions (e.g. Threlkeld \& Drenner 1987, Kuuppo-Leinikki et al. 1994); nutrient cycling and response to enrichment (e.g. Kelly et al. 1985, Oviatt et al. 1995, Chen et al. 2000); benthic-pelagic coupling (e.g. Threlkeld 1994); and contaminant effects (e.g. Kuiper 1981, Perez et al. 1991). Although container walls define experimental volume and help regulate material and energy exchange with external environ- 
ments, walls are also potential sites of inadvertent biological and chemical activities (Confer 1972, Eppley et al. 1978, Dudzik et al. 1979). Consequently, ecosystem dynamics and community interactions can be altered by periphytic growth on mesocosm walls (Harte et al. 1980, Chen et al. 1997).

Wall periphyton communities are analogous to assemblages growing on hard substrates in nature; however, their importance is exaggerated in experimental ecosystems due to a relatively higher ratio of surface area to water volume compared to most natural ecosystems (Dudzik et al. 1979). Wall periphyton can dominate algal biomass and gross primary production within short time periods (Rees 1979, Chen et al. 1997). Algal growth on mesocosm walls has been shown to significantly alter ambient light fields (Eppley et al. 1978), nutrient uptake and regeneration (Confer 1972, Chen et al. 2000) and trophic interactions (de Lafontaine \& Leggett 1987) in experimental ecosystems. Recent studies have demonstrated that growth of wall periphyton and partitioning of primary production and nutrient uptake among wall, plankton and sediment habitats scale to the dimension of experimental containers (Chen et al. 1997, 2000).

Despite the widespread concern about experimental artifacts associated with wall periphyton (e.g. Dudzik et al. 1979), a surprisingly small proportion $(<5 \%)$ of mesocosm studies indicate wall-cleaning in their experimental protocols (Petersen et al. 1999; our Table 1). Among the relatively few studies with routine wall-cleaning, a wide range of cleaning frequencies have been reported from daily to fortnightly intervals (Petersen et al. 1999; our Table 1). Although frequent cleaning may minimize 'wall effects,' the procedure is often logistically difficult and may alter nutrient and light regimes in experimental ecosystems (Eppley et al. 1978, Dudzik et al. 1979, Pilson et al. 1980).

In this study, we investigated how periphyton removal from container walls affects experimental ecosystem dynamics and how these effects vary the with size and shape of experimental containers. Specific questions addressed here include the following: (1) Does wall-cleaning treatment significantly change ecological properties of specific assemblages and habitats (e.g. biomass, taxonomic composition and productivity of periphytic, planktonic and sediment algae, and abundances of bacterioplankton and benthic macrofauna) and of the integrated ecosystem (total nutrient content, algal biomass, and gross primary production)? (2) Are the responses of these ecological properties to routine wall-cleaning affected by the frequency of this treatment? (3) Do these responses to wall-cleaning vary with mesocosm dimensions?
Table 1. Periphyton removal from enclosure wall surfaces in a survey (364 studies) of aquatic mesocosms

\begin{tabular}{|lc|}
\hline Wall-cleaning frequency & No. of studies \\
\hline Daily & $5^{\mathrm{a}}$ \\
Twice weekly & $6^{\mathrm{b}}$ \\
Weekly or less & $6^{\mathrm{c}}$ \\
No cleaning indicated & $347^{\mathrm{d}}$ \\
a Edmondson (1955), Perez et al. (1977), Ringelberg \& \\
Kersting (1978), Heinle et al. (1979), Painting et al. (1989) \\
${ }^{\mathrm{b} O v i a t t ~ e t ~ a l . ~(1984), ~ L e v i n ~(1986), ~ O v i a t t ~ e t ~ a l . ~(1986), ~}$ \\
Rudnick \& Oviatt (1986), Goldsborough \& Kemp (1988), \\
Sampou \& Oviatt (1991) \\
${ }^{\text {c} R a y m o n t ~ \& ~ M i l l e r ~(1962), ~ G a m b l e ~ e t ~ a l . ~(1977), ~ G r i c e ~ e t ~ a l . ~}$ \\
(1980), Doering \& Oviatt (1986), Burkholder et al. (1992), \\
Neundorfer \& Kemp (1993) \\
dd Refer to Petersen et al. (1999) for complete list \\
\hline
\end{tabular}

Table 2. Physical variables of experimental estuarine ecosystems. Mesocosms are designated as A, B, C, D, and E in order of increasing diameter

\begin{tabular}{|c|c|c|c|c|c|}
\hline \multirow{2}{*}{$\begin{array}{l}\text { Physical } \\
\text { variable }\end{array}$} & \multicolumn{5}{|c|}{ Mesocosm designation } \\
\hline & $\mathrm{A}$ & $\mathrm{B}$ & $\mathrm{C}$ & $\mathrm{D}$ & $\mathrm{E}$ \\
\hline Volume $\left(\mathrm{m}^{3}\right)$ & 0.10 & 0.10 & 1.00 & 10.00 & 10.00 \\
\hline Depth (m) & 1.00 & 0.46 & 1.00 & 2.15 & 1.00 \\
\hline Radius (m) & 0.18 & 0.26 & 0.57 & 1.22 & 1.78 \\
\hline Wall area/volume $\left(\mathrm{m}^{-1}\right)$ & 11.25 & 7.68 & 3.54 & 1.64 & 1.12 \\
\hline
\end{tabular}

\section{MATERIALS AND METHODS}

Experimental design. Studies were conducted using a series of replicate mesocosms of different size and shape. Mesocosms ranged in volume from 0.1 to $10.0 \mathrm{~m}^{3}$, with depth and radius ranging from approx. 0.5 to $2.2 \mathrm{~m}$ and 0.2 to $1.8 \mathrm{~m}$, respectively; systems were designated A, B, C, D, and E in order of increasing radius (Table 2). Experimental treatment is defined as the regular removal of periphyton communities from container walls, with parallel mesocosms receiving no wall-cleaning designated as controls. Material removed from walls was left in the respective mesocosms to avoid altering mass balances of nutrients and organic matter (Neundorfer \& Kemp 1993). Treatments were effected using an abrasive scrub cloth (3M Scotchbrite Scrubber Pads) fixed to wooden plates on poles which extended the whole depth of each mesocosm; the entire inner surfaces of the walls were scraped with each treatment.

The primary experiment involved a 6 wk study (31 January to 15 March 1996) using 6 replicate mesocosms of 3 different dimensions (A, B, C; 0.1 to $1.0 \mathrm{~m}^{3}$; Tables $2 \& 3)$. For each size of mesocosm, replicate sys- 
tems were randomly separated into 2 groups, one treated and one serving as a control. Material was removed from the wall surfaces of treated mesocosms at twice-weekly ( 3 to $4 \mathrm{~d}$ ) intervals, while material was allowed to accumulate on the walls of control systems throughout the experiment. In addition, the effects of cleaning frequency ( $1 \mathrm{wk}^{-1}$ versus $2 \mathrm{wk}^{-1}$ ) were considered by comparing the results for the mid-radius mesocosms (B tanks) from this primary study with measurements from an earlier experiment in which these same systems were treated with weekly wallcleaning (Table 3, Expt 2). Similarly, to broaden our interpretation of how effects of wall-cleaning might vary with mesocosm dimension, we also compared results from 2 earlier experiments-one with no wallcleaning and one with weekly cleaning-involving mesocosms of 5 different dimension (Table 3, Expt 3).

Experimental systems. Cylindrical mesocosms were constructed of fiberglass-reinforced glazing material (Sun-Lite ${ }^{\circledR}$ ) and housed in a temperature-controlled room. Water temperatures exhibited small diel variation, and mesocosms were illuminated by banks of fluorescent bulbs (supplemented with incandescent bulbs in the 1994 experiment) in a $12 \mathrm{~h}$ light:12 h dark cycle with mean surface light intensity of $155 \mu \mathrm{E} \mathrm{m} \mathrm{m}^{-2} \mathrm{~s}^{-1}$ (range 147 to $160 \mu \mathrm{E} \mathrm{m}^{-2} \mathrm{~s}^{-1}$, Table 4). An air conditioning system in the mesocosm facility, combined with insulation on the outer walls of each container, helped to maintain relatively constant water temperatures between experimental seasons and among different experimental systems, with mean values ranging from 19.7 to $22.7^{\circ} \mathrm{C}$ (Chen 1998). Mixing was accomplished by means of large, slow-moving PVC paddles, which produced relatively uniform turbulence typical of estuarine surface waters (Sanford 1997). All mesocosms were initiated with natural sediments and unfiltered estuarine water (salinity 8 to $12 \mathrm{psu}$ ) from the Chop-

Table 3. Experimental design

\begin{tabular}{|c|c|c|c|c|}
\hline $\begin{array}{l}\text { Expt } \\
\text { no. }\end{array}$ & $\begin{array}{l}\text { Cleaning } \\
\text { frequency }\end{array}$ & $\begin{array}{l}\text { Mesocosms } \\
\text { involved }^{\mathrm{a}}\end{array}$ & $\begin{array}{l}\text { Comments } \\
\text { (timing) }\end{array}$ & $\begin{array}{l}\text { Research } \\
\text { question }\end{array}$ \\
\hline 1 & $2 \mathrm{wk}^{-1}$ & A, B, C & $\begin{array}{l}\text { Primary Experiment } \\
\text { (31 Jan-15 Mar 96) }\end{array}$ & $\begin{array}{l}\text { Wall-cleaning } \\
\text { effects }\end{array}$ \\
\hline 2 & $1 \mathrm{wk}^{-1}$ & B & $\begin{array}{c}\text { Comparison of Expt } 1 \\
\text { with earlier study } \\
\text { (25 Jul-21 Aug 95) }\end{array}$ & $\begin{array}{c}\text { Wall-cleaning } \\
\text { frequency }\end{array}$ \\
\hline 3 & $1 \mathrm{wk}^{-1}$ & $\begin{array}{l}\mathrm{A}, \mathrm{B}, \mathrm{C} \\
\mathrm{D}, \mathrm{E}\end{array}$ & $\begin{array}{l}\text { Comparison across wider } \\
\text { range of container sizes } \\
\text { and shapes with and } \\
\text { without wall-cleaning } \\
\text { (Expt 2, Jul-Aug 95 } \\
\text { Expt 3, Jul-Aug 94) }\end{array}$ & $\begin{array}{c}\text { Wall-cleaning } \\
\text { effects across } \\
\text { wider scales }\end{array}$ \\
\hline
\end{tabular}

Table 4. Mean photosynthetically available radiation $\left(\mathrm{PAR}_{i}\right.$ $\mu \mathrm{E} \mathrm{m}^{-2} \mathrm{~s}^{-1}$ ) at water surface and water temperature (Temp; ${ }^{\circ} \mathrm{C}$ ) over the course of experiment. Temperature values are mean \pm diel range. PAR values are mean \pm SE of replicate $(n=3)$ mesocosms

\begin{tabular}{|llcc|}
\hline Tank & Treatment & PAR & Temp \\
\hline A & Control & $157 \pm 4.1$ & $18.6 \pm 1.5$ \\
& Cleaned & $147 \pm 5.4$ & $18.3 \pm 1.5$ \\
B & Control & $150 \pm 1.9$ & $21.0 \pm 2.4$ \\
& Cleaned & $160 \pm 4.2$ & $19.0 \pm 2.3$ \\
C & Control & $158 \pm 5.6$ & $19.6 \pm 1.6$ \\
& Cleaned & $160 \pm 4.8$ & $19.2 \pm 1.6$ \\
\hline
\end{tabular}

tank River estuary, a tributary of the Chesapeake Bay, USA. A portion $(10 \%)$ of the water volume of each mesocosm was drained and replaced with filtered $(0.5 \mu \mathrm{m})$ estuarine water daily. During a $10 \mathrm{~d}$ batch period (Days 25 to 35) of the primary experiment, water was not exchanged in order to allow depletion of nutrient levels. A nutrient pulse was administered in the primary experiment on Day 34 to bring concentrations of ammonium $\left(\mathrm{NH}_{4}{ }^{+}\right)$, phosphate $\left(\mathrm{PO}_{4}{ }^{3-}\right)$ and silica (dSi) up to 50, 3.1 and $50 \mu \mathrm{M}$, respectively. Similar nutrient pulse treatments were effected on Day 14 of the 1995, and Day 31 of the 1994 studies (Chen et al. 1997).

Sampling and analysis. Key properties and processes measured in this study include: light intensity, nutrient concentration, algal biomass and taxonomic composition (phytoplankton, wall periphyton, sediment microalgae), bacterioplankton abundance, benthic macrofaunal biomass and taxonomic composition, and primary productivity and respiration both for total ecosystem and for planktonic and periphytic components. The vertical distribution of photosynthetically available radiation (PAR) was measured weekly using hemispherical sensors (Li Cor, $2 \pi$ ).

Dissolved inorganic nutrient concentrations $\left(\mathrm{NH}_{4}{ }^{+}, \mathrm{NO}_{3}{ }^{-}+\mathrm{NO}_{2}{ }^{-}, \mathrm{PO}_{4}{ }^{3-}\right.$, and $\mathrm{dSi})$ were sampled twice-weekly and water column chlorophyll a (chl a) was sampled daily. Standard automated wet chemical methods were used to measure nutrient concentrations (Technicon AAII autoanalyzer) following filtration through precombusted GF/F filters (Parsons et al. 1984). In vivo water column chl a concentrations were determined fluorometerically (WET Labs Model 9602004), with measurements calibrated both by in vitro fluorometry (Turner Designs Model 10) following 
extraction with $90 \%$ acetone and by high performance liquid chromatography (HPLC; Van Heukelem et al. 1994).

Periphytic growth on mesocosm walls was measured by deploying and retrieving fiberglass strips fabricated from wall material. Replicate fiberglass strips were attached to mesocosm walls at the beginning of each experiment (Chen et al. 1997). Strips were removed periodically before wall-cleaning treatments, and used to estimate biomass and rates of periphyton primary production and respiration (see below). Occasionally, strips were retrieved both before and after cleaning treatments to assess cleaning efficiency. Scraped material was extracted in $90 \%$ acetone and sonicated to aid pigment extraction (Whitney \& Darley 1979, Chen et al. 1997). After centrifugation, extracted chl $a$ was measured by fluorometry and calibrated with HPLC.

Biomass of sediment microalgae was estimated weekly in the primary experiment using chl $a$ as an index. Sediment was collected using small $(2.6 \mathrm{~cm}$ diam.) sediment cores. The top $1 \mathrm{~cm}$ of sediment samples was placed in a centrifuge tube and extracted in $100 \%$ acetone, followed by a phase-separation spectrophotometric acidification technique (Whitney \& Darley 1979). Chl a concentrations in hexane extracted samples were measured with a spectrophotometer (Milton Roy, Spectronic 301), calibrated by HPLC. Biomass values for both wall periphyton and sediment microalgae are reported as $\mathrm{mg} \mathrm{m}^{-2}$ of sampled wall or sediment area, respectively. To compare with phytoplankton biomass $\left(\mathrm{mg} \mathrm{m}^{-3}\right)$, these data were also converted to $\mathrm{mg} \mathrm{m}^{-3}$ basis by multiplication by the respective ratios of wall area/water volume or sediment area/water volume (see Table 2 ).

Taxonomic compositions of planktonic, benthic, and periphytic algae were assessed using accessory pigment composition as an index. Samples were collected 1 to $4 \mathrm{~d}$ after nutrient addition and analyzed with HPLC (Van Heukelem et al. 1994). Multivariate regressions (Bidigare et al. 1986, Letelier et al. 1993, Barlow et al. 1995) were used to assess characteristic pigment ratios.

Abundance of bacterioplankton was measured weekly by acridine orange direct cell counts (Hobbie et al. 1977). Water samples were fixed with aqueous glutaraldehyde, stained with acridine orange, and filtered onto blackened $0.22 \mu \mathrm{m}$ polycarbonate filters with $0.65 \mu \mathrm{m}$ backing filters. Bacterioplankton cells were counted using a Zeiss Axiophot microscope at $1612 \times$ final magnification (Sanford et al. 2001).

Biomass and taxonomic composition of benthic macrofauna were measured at the beginning and end of experiment. Sediment cores $(13.2 \mathrm{~cm}$ diam.) were sampled and sieved through $0.5 \mathrm{~mm}$ screens. Samples were immediately stained with Rose Bengal and preserved in $10 \%$ buffered formalin for subsequent species identification and weighing.

Rates of primary productivity and respiration for whole experimental ecosystems were continuously monitored by tracing changes in dissolved oxygen $\left(\mathrm{O}_{2}\right)$ concentration in situ using a series of galvanic $\mathrm{O}_{2}$ sensors (OxyGuard Stationary probes) which were deployed in each mesocosm. These electrodes were calibrated twice-weekly with standard Winkler titration techniques (Carritt \& Carpenter 1966). Net primary production (NPP) was taken as the net $\mathrm{O}_{2}$ production during the light period. The decrease in $\mathrm{O}_{2}$ concentration during daily $12 \mathrm{~h}$ dark periods was used to compute respiration (R). Gross primary production (GPP) was defined operationally as the sum of R (taken as a positive number) and NPP (Odum 1956, Oviatt et al. 1995, Chen et al. 1997). These metabolic rates were adjusted for air-water gas exchange with diffusion coefficients measured in a previous study (Petersen et al. 1997).

Rates of primary production and respiration for plankton and wall communities were determined periodically by measuring dawn-dusk-dawn changes in $\mathrm{O}_{2}$ concentration in incubation chambers over $24 \mathrm{~h}$ periods (Petersen \& Chen 1999). Chambers were constructed of clear acrylic tubes $(7 \mathrm{~cm}$ diam.) which extended the whole depth of each mesocosm. Water in each chamber was stirred by an internally mounted stir-bar, and the top and bottom of each chamber were sealed with transparent acrylic caps to exclude sediments and eliminate gas exchange with the atmosphere (Petersen \& Chen 1999). Two chambers were incubated concurrently in each mesocosm, one with ambient water only and the other with both water and a wall strip with periphyton growth. NPP, R and GPP values of plankton communities were estimated from the chambers with water only. These values were subtracted from those measured in chambers containing strips of wall material to estimate metabolic rates of the periphyton community.

Statistical analysis. Statistical analyses were performed using SYSTAT (1992) software. Repeatedmeasures analysis (Crowder \& Hand 1990) was used to assess differences between treatments and controls in nutrient concentrations, autotrophic biomass, and GPP of whole ecosystems, as well as plankton and wall communities. In this case, significant differences were tested using $\mathrm{p}$-values for treatment $\left(\mathrm{p}_{1}\right)$ and time $\times$ treatment $\left(\mathrm{p}_{2}\right)$ effects. For most variables in the primary experiment (1996), effects of treatment were also analyzed by simple ANOVA on data pooled into 3 different time periods: initial (Days 1 to 24), batch (Days 25 to 35), and post-nutrient (Days 36 to 45). For the 2 secondary experiments $(1994,1995)$ comparing clean- 
ing treatment versus control and weekly versus twiceweekly cleaning in separate time periods (Table 3 ), we tested for treatment effects using only ANOVA. Here, we assumed that the wall-cleaning treatment was the only difference between the separate experiments. Where appropriate, Fisher's least significant difference test (LSD) was used to identify differences between means.

Multivariate linear regressions of accessory pigments against chl a were used to determine the presence of major algal groups in each mesocosm habitat (plankton, sediments, periphyton) using the pigment biomarker method (Hooks et al. 1988, Millie et al. 1993). In this approach, it was assumed that alloxanthin is attributed exclusively to cryptophytes, that fucoxanthin is associated with diatoms, that lutein indicates chlorophytes, that peridinin indicates dinoflagellates, and that zeaxanthin is associated with cyanobacteria. We ignored the fact that a small fraction of fucoxanthin may be attributed to dinoflagellates when both diatom and dinoflagellate are present (Millie et al. 1993). This analysis may also underestimate contributions of dinoflagellates because some species do not contain peridinin (Bjørnland \& Tangen 1979, Johnsen \& Sakshaug 1993). Linear regression analysis was used to examine the relationships between mesocosm radius and differences in mean biomass between treated and control systems for both phytoplankton and wall periphyton.

\section{RESULTS}

\section{Algal biomass}

Wall-cleaning treatment at twice-weekly intervals effectively eliminated periphytic algae biomass from mesocosm walls over the course of experiment (Fig. 1a-c). On one occasion, direct evidence of the efficiency of periphyton removal was obtained by comparing periphytic biomass before and after wall-cleaning, where biomass values were reduced from $0.016( \pm 0.011)$ to 0.005 $( \pm 0.002) \mathrm{mg}$ chl a m${ }^{-2}$ (mean $\left.\pm \mathrm{SE}\right)$. Overall, periphytic biomass values were significantly higher $\left(\mathrm{p}_{1}<0.05\right.$ for treatment, $\mathrm{p}_{2}>0.05$ for time $\times$ treatment) in the control than in the cleaned systems for each of the 3 sizes of mesocosm (A, B, C), with overall mean values of 3.7 and $0.03 \mathrm{mg} \mathrm{chl} \mathrm{a} \mathrm{m}^{-2}$, respectively. After the nutrient pulse treatment, periphytic biomass increased rapidly in all control containers but not in the cleaned systems (Fig. 1a-c).

Significant differences in phytoplankton biomass ( $\mathrm{mg} \mathrm{chl} \mathrm{a} \mathrm{m}^{-3}$ ) between control and cleaned systems over the whole experiment were evident only in the narrow A tanks $\left(\mathrm{p}_{1}\right.$ and $\left.\mathrm{p}_{2}<0.05\right)$. Significant treatment effects were, however, apparent in the postnutrient period for all 3 sizes of experimental system (Fig. 1d-f). During this period, phytoplankton biomass was higher in cleaned than in control systems in $\mathrm{A}\left(\mathrm{p}_{1}\right.$ and $\left.\mathrm{p}_{2}<0.01\right)$ and $\mathrm{B}\left(\mathrm{p}_{1}<0.05 ; \mathrm{p}_{2}=0.25\right)$ tanks (Fig. 1d,e). The pattern was, however, inverse for the C tanks ( $\mathrm{p}_{1}$ and $\left.\mathrm{p}_{2}<0.01\right)$, with the cleaned tanks having higher chl a during the batch mode and lower values following nutrient addition (Fig. 1f).

Sediment microalgal biomass $\left(\mathrm{m}^{-2}\right)$ was similar for all tanks and treatments throughout the experiment
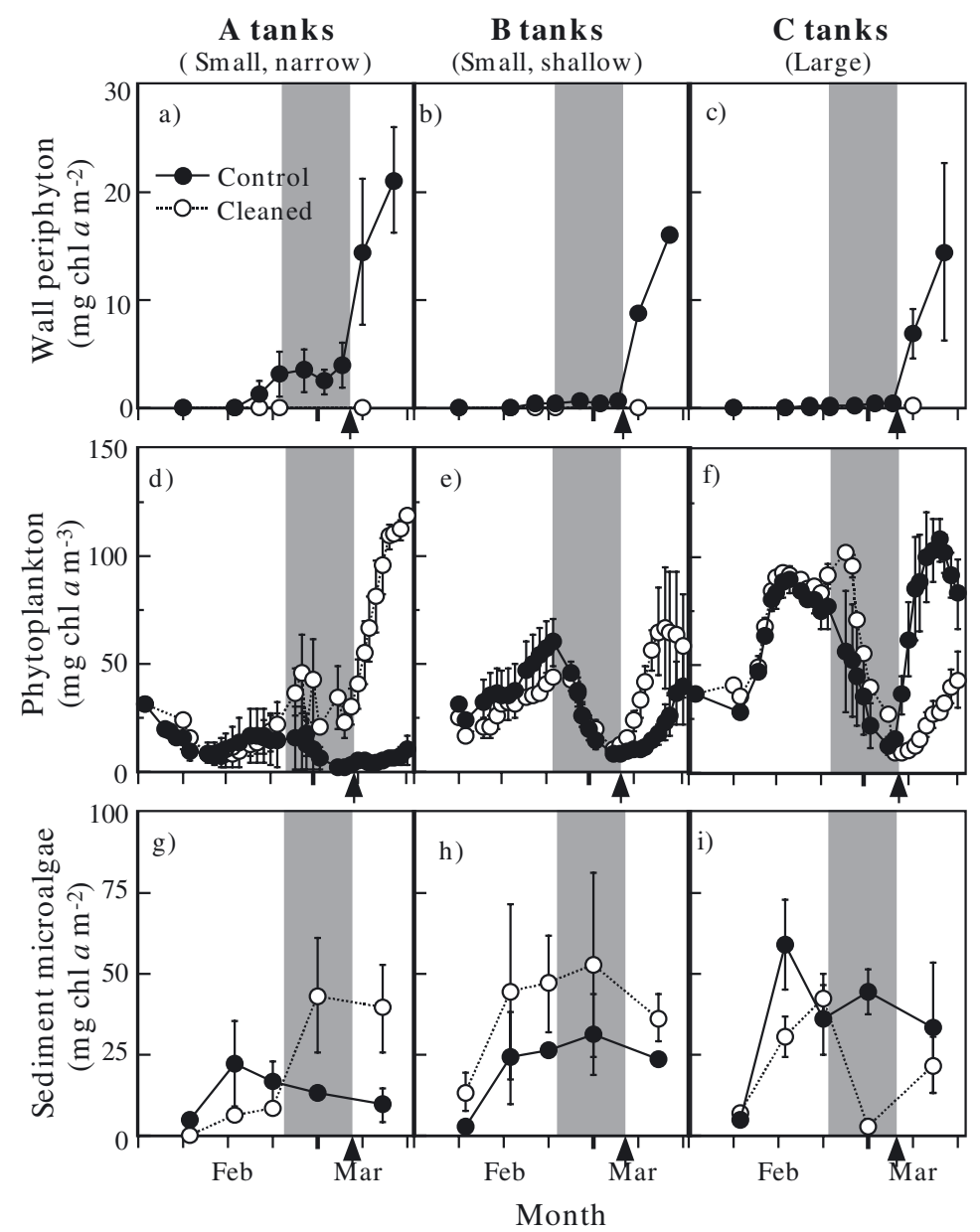

Fig. 1. Biomass time-course $(\mathrm{mg} \mathrm{chl} a)$ of $(\mathrm{a}-\mathrm{c})$ wall periphyton $\left(\mathrm{m}^{-2}\right.$ wall area), (d-f) phytoplankton $\left(\mathrm{m}^{-3}\right.$ water volume), and $(\mathrm{g}-\mathrm{i})$ sediment microalgae $\left(\mathrm{m}^{-2}\right.$ sediment area) of control $(\bullet)$ and twice-weekly cleaned (O) systems in A, B and C tanks. Values are mean $\pm \mathrm{SE}$ of replicate $(\mathrm{n}=3)$ mesocosms. Batch mode is indicated by the shaded area, and the nutrient pulse is indicated by the arrow on the $\mathrm{x}$-axis 


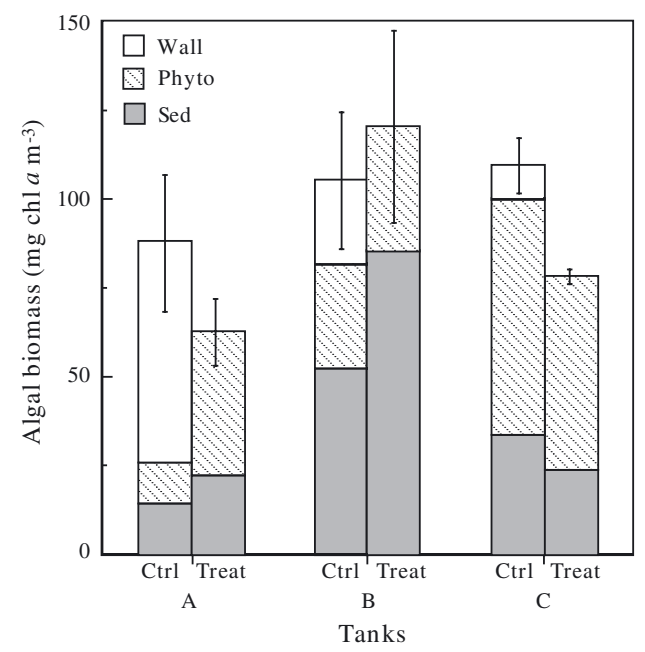

Fig. 2. Mean total algal biomass [phytoplankton (phyto) + sediment microalgae (sed) + wall periphyton (wall)] of controls and twice-weekly cleaned systems in A, B, and C tanks. Standard errors are shown for each treatment and mesocosm type

(Fig. 1g-i); however, different treatment effects were evident among different size systems. Wall-cleaning treatment resulted in significantly higher benthic microalgal biomass for both of the smaller $\left(0.1 \mathrm{~m}^{3}\right)$ mesocosm types, with differences in narrow (A) tanks being delayed and less pronounced (20.8 vs $13.6 \mathrm{mg}$ $\mathrm{chl} \mathrm{a} \mathrm{m}^{-2}$ ) compared to those (38.7 vs $22.8 \mathrm{mg} \mathrm{chl} \mathrm{a} \mathrm{m}^{-2}$ ) in the shallower (B) tanks. In contrast, mean biomasses in the larger $\left(1 \mathrm{~m}^{3}\right) \mathrm{C}$ tanks were variable but generally higher in the control systems, with values of 33.8 and

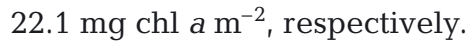

Total algal biomass $(\mathrm{TA}=$ phytoplankton + sediment microalgae + wall periphyton) was not significantly affected by wall-cleaning treatment in A and B tanks. Small treatment effects on TA were evident $(p<0.05)$ in the larger $\mathrm{C}$ tanks, where wall-cleaning decreased biomass by $25 \%$ (Fig. 2). Relative contributions of the 3 algal components to TA varied with treatment and among experimental systems with different dimensions (Fig. 2). The untreated controls with highest TA values were found in $C$ tanks, those with intermediate values in the $\mathrm{B}$ systems, and those with lowest values in the narrow A tanks. The contribution of phytoplankton to TA increased linearly with container radius in control systems $\left(r^{2}=0.88, p<0.01\right)$. The pattern was reversed for wall communities, where periphyton contributions decreased with container radius $\left(\mathrm{r}^{2}=0.39\right.$, $\mathrm{p}=0.07$ ). Biomass of sediment microalgae in untreated controls was highest in the shallow B tanks, intermediate in the larger $\mathrm{C}$ tanks, and lowest in the narrow $\mathrm{A}$ tanks. Similarly, in mesocosms receiving wall-cleaning treatment, TA followed the same rank order B $>\mathrm{C}>\mathrm{A}$ (Fig. 2). Because wall periphyton were efficiently elim- inated with cleaning, they contributed little to TA in treated systems. Phytoplankton comprised over $60 \%$ of total algal biomass in the treated $\mathrm{A}$ and $\mathrm{C}$ tanks. In contrast, more than $70 \%$ of algal biomass was comprised of sediment microalgae in the shallow B tanks (Fig. 2). When all data are pooled, sediment microalgae biomass is linearly related to bottom light intensity $\left(\mathrm{r}^{2}=0.60, \mathrm{p}<0.01\right)$.

\section{Algal taxonomic composition}

The results of multiple regression models of 5 key accessory pigments (alloxanthin [allo], fucoxanthin [fuco], lutein, peridinin [perid], zeaxanthin [zeax]) against chl a were highly significant for each of the 3 algal habitat assemblages $\left(r^{2}=0.99, p<0.01\right)$. Equations were as follows: phytoplanktonic chl $a=2.19$ [fuco] +6.04 [lutein] +2.22 [perid] +1.19 [zeax]; sediment microalgal chl $a=2.07$ [fuco] +3.45 [lutein] +0.32

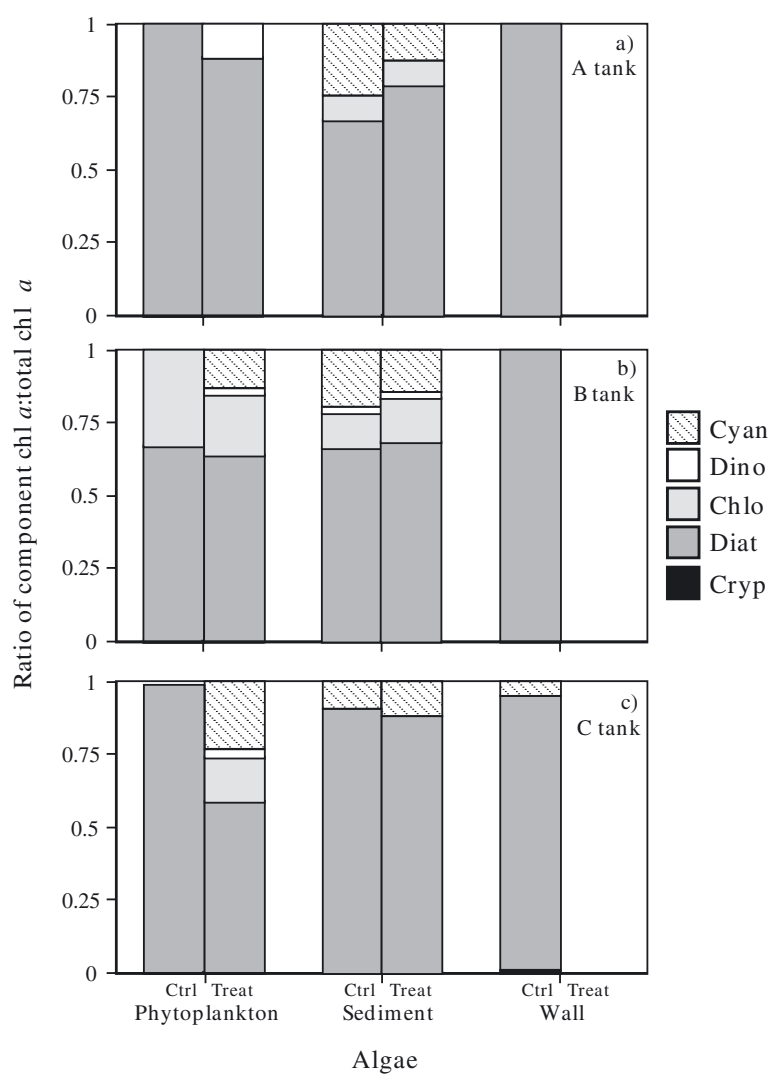

Fig. 3. Ratio of accessory pigments to total chl a in plankton, wall, and benthic habitats in controls and twice-weekly cleaned systems in A, B, and C tanks. Samples were collected 1 to $4 \mathrm{~d}$ after nutrient addition, and no wall periphyton samples were taken from the treated systems. Chlo = Chlorophytes; Cryp = Cryptophytes; Cyan = Cyanobacteria; Diat $=$ Diatoms; Dino = Dinoflagellates 
[perid] +1.59 [zeax]; wall periphytic chl $a=2.17$ [fuco] +9.23 [zeax] + 0.78 [allo]. These regression coefficients were multiplied by observed accessory pigment concentrations to estimate the contribution of cells bearing these pigments to total algal biomass for each system.

Overall, the strongest effects of treatment on algal taxonomic composition were evident for phytoplankton, with little effect apparent for either sediment microalgae or wall periphyton. All mesocosm algal communities were dominated by diatoms (fucoxanthin) (Fig. 3). Dinoflagellates (peridinin) were also relatively abundant in phytoplankton in treated A tanks, but not in controls (Fig. 3a). Diatoms and chlorophytes (lutein) occurred in all the B tanks, with dinoflagellates and cyanobacteria (zeaxanthin) also evident in treated B tanks (Fig. 3b). Phytoplankton composition in treated C tanks was similar to that in treated B tanks, with diatoms dominant and relatively few cyanobacteria in controls (Fig. 3c).

Very few effects of treatment on taxonomic composition were apparent for sediment microalgae in any mesocosm size (Fig. 3). Sediment microalgae were also dominated by diatoms, with cyanobacteria, chlorophytes (A and B tanks) and dinoflagellates (B tanks) also present. Wall periphyton was entirely composed of diatoms in A and B tanks (Fig. 3a,b), with small proportions of cyanobacteria and cryptophytes in the control C tanks (Fig. 3c).

\section{Gross primary production (GPP)}

Dynamics of total ecosystem GPP were similar among mesocosms of different dimensions, with rates $\left(\mathrm{m}^{-3}\right)$ slightly higher in $\mathrm{B}$ and $\mathrm{C}$ compared to A systems. The effects of treatment on whole system GPP were generally negligible over the course of the experiments (Fig. $4 \mathrm{a}-\mathrm{C}$ ). In the period following nutrient addition, however, rates in $\mathrm{C}$ tanks were significantly decreased with treatment (Fig. $4 \mathrm{C}_{\text {; }}$ $\left.\mathrm{p}_{1}<0.05 ; \mathrm{p}_{2}<0.01\right)$. In contrast, GPP rates for planktonic components were significantly enhanced with wall-cleaning treatment $\left(\mathrm{p}_{1}<\right.$ $0.01 ; \mathrm{p}_{2}<0.05$ ) in the narrow A tanks (Fig. 4d). Although similar effects on B tank plankton were evident during the post-nutrient period, there were no significant effects of treatment for either B or C tanks (Fig. 4e,f). Mean values of wall community GPP appeared to decrease with wall-cleaning; however, variance was high and differences were not significant (Fig. $4 g-i$ ).

\section{Nutrient concentrations}

Temporal variations in nutrient (dissolved inorganic nitrogen [DIN], phosphate $\left[\mathrm{PO}_{4}{ }^{3-}\right]$, and silica [dSi]) concentrations were similar in treated and control systems throughout the experiment in mesocosms of all 3 dimensions (Fig. 5). Even though mean nutrient concentrations were consistently higher in treated systems following nutrient input, these differences were not significant for most nutrients. The only significant treatment effect $\left(p_{1}\right.$ and $\left.p_{2}<0.01\right)$ was for dSi concentrations in $\mathrm{C}$ tanks (Fig. 5i).

\section{Bacterioplankton}

Bacterioplankton abundances were similar in treated and control mesocosms during initial and batch
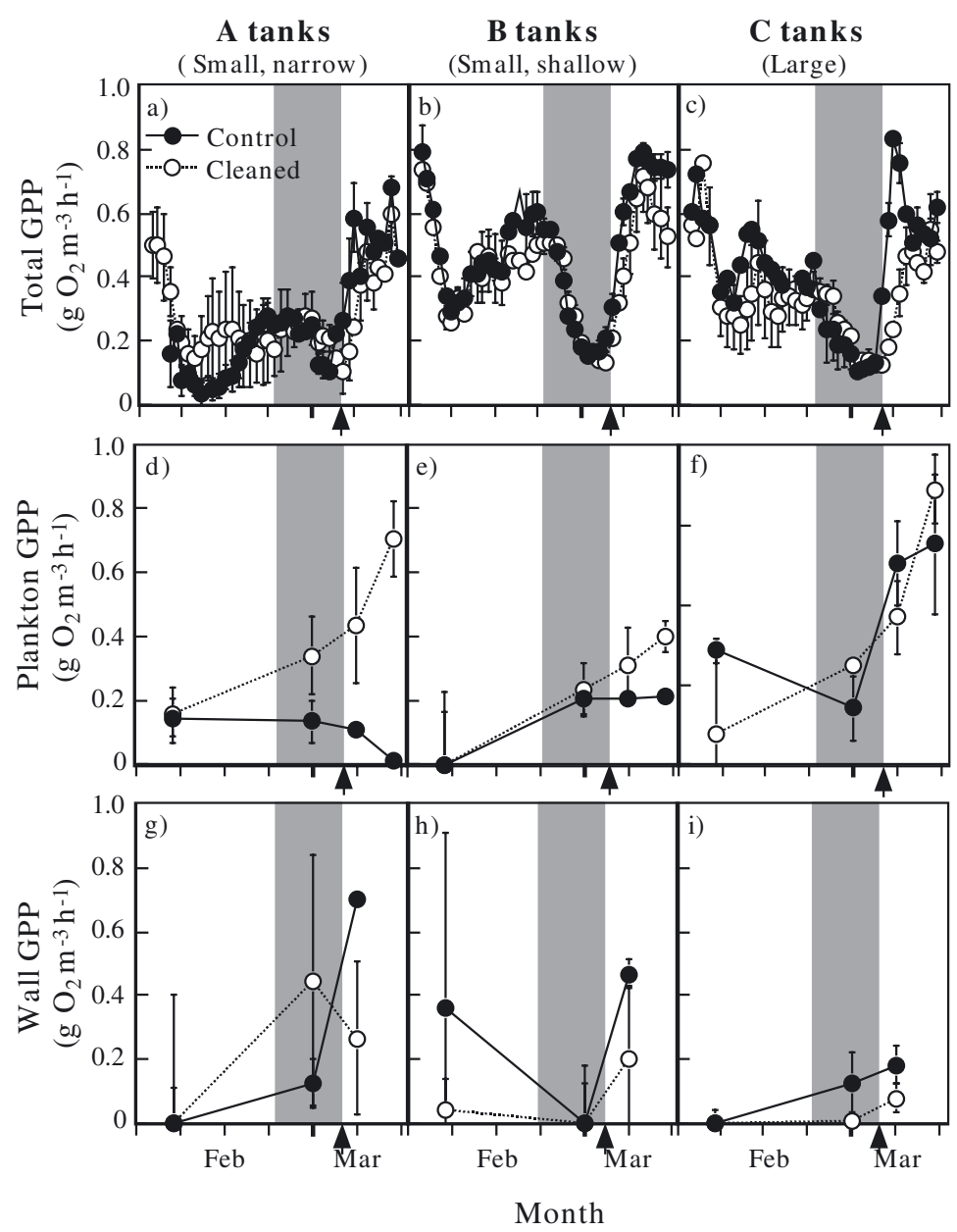

Fig. 4. Gross primary production (GPP) time-course of $(\mathrm{a}-\mathrm{c})$ total ecosystem, $(\mathrm{d}-\mathrm{f})$ planktonic and $(\mathrm{g}-\mathrm{i})$ wall communities in control $(\bullet)$ and twiceweekly cleaned $(\mathrm{O})$ systems in A, B and C tanks. Values are mean $\pm \mathrm{SE}$ of replicate $(n=3)$ mesocosms. Batch mode is indicated by the shaded area, and the nutrient pulse is indicated by the arrow on the $\mathrm{x}$-axis 

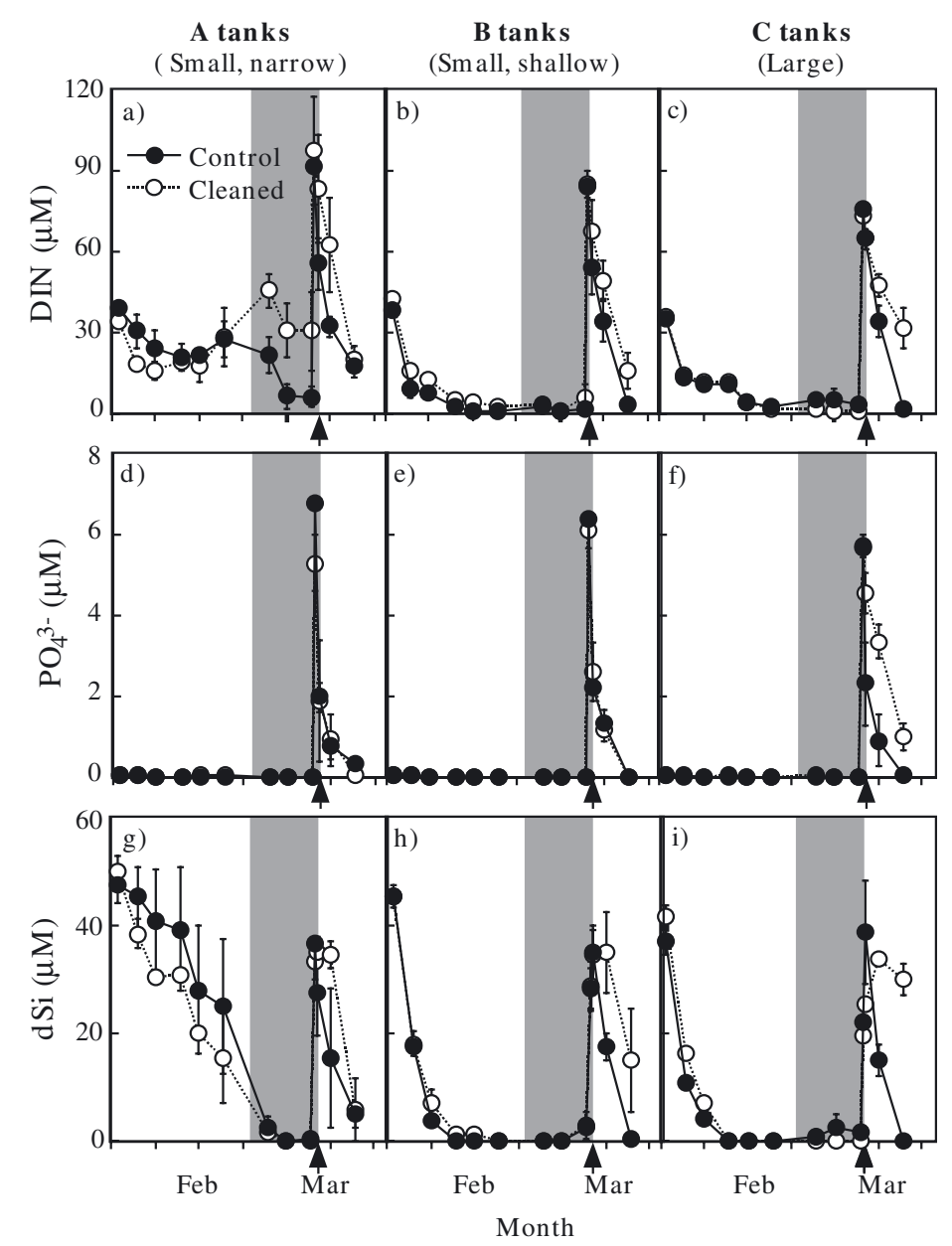

Fig. 5. Time-course of $(\mathrm{a}-\mathrm{c})$ dissolved inorganic nitrogen (DIN), $(\mathrm{d}-\mathrm{f})$ phosphate $\left(\mathrm{PO}_{4}{ }^{3-}\right)$, and $(\mathrm{g}-\mathrm{i})$ silica $(\mathrm{dSi})$ concentration in control $(\bullet)$ and twice-weekly cleaned (O) systems in A, B and C tanks. Values are mean \pm SE of replicate $(n=3)$ mesocosms. Batch mode is indicated by the shaded area, and the nutrient pulse is indicated by the arrow on the $\mathrm{x}$-axis

periods in all 3 systems (Table 5). In the post-nutrient period, bacterioplankton abundances were significantly higher in treated systems in B $(p<0.01)$ and $\mathrm{C}(\mathrm{p}<0.05)$ tanks, but not in the A tanks. Bacterioplankton abundances over the whole experimental duration were significantly elevated in treated B and C (both $\mathrm{p} \leq 0.01$ ) tanks; however, this trend is clearly driven by the large differences during the post-nutrient period (Table 5).

\section{Benthic macrofauna}

Sediment samples collected near the beginning of the experiment revealed that the benthic macrofauna were dominated by 3 phyla (i.e. Annelida, Arthropoda, and Insecta) with mean total biomass $( \pm \mathrm{SE})$ of $4.3( \pm 1.4) \mathrm{g}$ wet weight $\mathrm{m}^{-2}$ for all experimental systems. By the end of the experiment total benthic biomass ranged from about 8 to $30 \mathrm{~g}$ wet weight $\mathrm{m}^{-2}$, and communities were dominated by both annelids (i.e. polychaetes and oligochaetes) and arthropods (i.e. amphipods and isopods) in all mesocosms (Table 6). Insects were also found in the A and $\mathrm{C}$ tanks, and cnidarians (anemone) were observed in the B tanks. Mean macrofaunal biomass values were consistently 30 to $250 \%$ higher in treated mesocosms (Table 6). Variability was generally high, however, and wallcleaning effects were significant only for the biomass of insects and the total benthic macrofaunal community in $\mathrm{C}$ tanks.

\section{Wall-cleaning frequency}

Comparison of ecosystem properties in B tanks cleaned twice-weekly during the 1996 experiment with those measured in an earlier (1995) experiment employing once-weekly wall-cleaning (see Table 3) provided a tentative test for the effects of varying wall-cleaning frequency. Periphyton communities were not efficiently removed from B tanks subjected to weekly wall-cleaning treatment (Table 7). Whereas twice-weekly cleaning resulted in significant (100-fold) periphyton reductions, weekly cleaning resulted in a decrease in mean periphytic biomass of only $40 \%$ (from 1.6

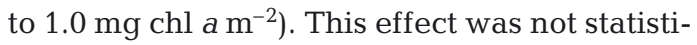
cally significant (Table 7).

Although wall-cleaning at either frequency $\left(1 \mathrm{wk}^{-1}\right.$ or $\left.2 \mathrm{wk}^{-1}\right)$ resulted in generally higher mean biomass values for phytoplankton (18 to $35 \%$ ) and sediment microalgae $(84 \%)$, differences were not significant (Table 7). Similarly, although

Table 5. Mean bacterioplankton abundance $\left(\times 10^{9}\right.$ cells $\left.\mathrm{l}^{-1}\right)$. Values are average abundances of initial (Days 1 to 24), batch (Days 25 to 35 ), post-nutrient periods (Days 36 to 45 ), and over the whole experiment period of replicate $(n=3)$ mesocosms expressed as mean \pm SE. ${ }^{*} \mathrm{p}<0.05,{ }^{* *} \mathrm{p} \leq 0.01$

\begin{tabular}{|llcccl|}
\hline Tank & Treatment & Initial & Batch & Post & Whole \\
\hline A & Control & $3.2 \pm 0.6$ & $1.9 \pm 0.1$ & $3.3 \pm 0.8$ & $2.9 \pm 0.3$ \\
& Cleaned & $3.1 \pm 0.4$ & $2.2 \pm 0.5$ & $5.4 \pm 0.8$ & $3.4 \pm 0.4$ \\
B & Control & $2.8 \pm 0.2$ & $2.9 \pm 0.3$ & $2.0 \pm 0.3^{* *}$ & $2.6 \pm 0.2^{* *}$ \\
& Cleaned & $3.2 \pm 0.2$ & $3.6 \pm 0.5$ & $7.4 \pm 1.0^{* *}$ & $4.3 \pm 0.5^{* *}$ \\
C & Control & $2.9 \pm 0.2$ & $2.7 \pm 0.5$ & $4.3 \pm 0.8^{*}$ & $3.2 \pm 0.3^{* *}$ \\
& Cleaned & $2.5 \pm 0.2$ & $2.3 \pm 0.1$ & $7.9 \pm 1.3^{*}$ & $3.8 \pm 0.6^{* *}$ \\
\hline
\end{tabular}


Table 6. Biomass ( $\mathrm{g}$ wet weight $\mathrm{m}^{-2}$ ) and taxonomic composition of benthic macrofauna at the end of experiment. Values are mean \pm SE of replicate $(n=3)$ mesocosms. ${ }^{*} p<0.05,-$ : no animals recorded

\begin{tabular}{|lcccc|}
\hline \multirow{2}{*}{ Macrofauna } & Treatment & \multicolumn{3}{c|}{ Mesocosm designation } \\
& & A & B & C \\
\hline Annelida & Control & $18.1 \pm 16.6$ & $6.6 \pm 2.8$ & $9.4 \pm 1.1$ \\
& Cleaned & $26.0 \pm 21.8$ & $20.4 \pm 14.6$ & $16.9 \pm 5.6$ \\
Arthropoda & Control & $1.2 \pm 0.6$ & $1.2 \pm 0.7$ & $2.1 \pm 0.8$ \\
& Cleaned & $0.6 \pm 0.3$ & $7.2 \pm 2.1$ & $1.7 \pm 1.2$ \\
Cnidaria & Control & - & $0.1 \pm 0.1$ & - \\
& Cleaned & - & $0.8 \pm 0.8$ & - \\
Insecta & Control & $0.7 \pm 0.7$ & - & $0.6 \pm 0.4^{*}$ \\
& Cleaned & $0.1 \pm 0.1$ & - & $3.7 \pm 0.7^{*}$ \\
Total & Control & $20.1 \pm 15.6$ & $7.9 \pm 3.0$ & $12.1 \pm 2.0^{*}$ \\
& Cleaned & $26.6 \pm 21.5$ & $28.4 \pm 17.3$ & $22.2 \pm 6.6^{*}$ \\
& & & & \\
\hline
\end{tabular}

see Table 2) by comparing results from experiments conducted in the summers of successive years (see Table 3). To facilitate comparison of changes in periphyton and phytoplankton biomasses, both are expressed in units of $\mathrm{mg} \mathrm{chl} \mathrm{a}$ $\mathrm{m}^{-3}$ of water volume. Periphytic algal biomass (Table 8) was significantly higher on uncleaned mesocosm walls compared to those with weekly cleaning for mesocosms of all 5 dimensions. Mean phytoplankton biomass values were higher or similar in cleaned compared to control systems (Table 8). In spite of large (6- to 25-fold) and significant differences in periphytic biomass between treated and control meso-

small consistent differences were observed for other variables (e.g. GPP, DIN, $\mathrm{PO}_{4}{ }^{3-}$, dSi) with treatment, these were not statistically significant in either weekly or twice-weekly treatments (Table 7).

The coefficients of variability (variance/mean) for algal biomass and nutrient concentrations tended to be slightly higher for systems receiving wall-cleaning compared to controls, particularly at the twice-weekly frequency (Table 7). For GPP, however, there was no consistent change in relative variance with wall-cleaning at either frequency.

\section{Effects over a broader range of container dimensions}

Differences in wall-cleaning effects were also considered for all 5 container types (volume range 0.1 to $10 \mathrm{~m}^{3}$, cosms, treatment had much smaller and inconsistent effects on ecosystem GPP, with rates ranging from $30 \%$ higher to $50 \%$ lower. Relative variance (variance/mean) in GPP rates measured for replicate tanks were remarkably low, being less than 0.06 for 8 of 10 treatment replicates. Consequently, small (mean of $22 \%$ ) decreases in GPP with treatment in A, C, and D systems were detectable (Table 8).

Although periphytic biomass was significantly decreased by wall-cleaning treatment in all container types, there were significant negative correlations between periphyton chl $a$ and system radius for both control and treated systems, with $\mathrm{r}^{2}$ values of 0.57 ( $\mathrm{p}<$ $0.01)$ and $0.35(\mathrm{p}<0.05)$, respectively. In contrast, phytoplankton biomass tended to increase linearly with container radius for treated systems $\left(\mathrm{r}^{2}=0.35, \mathrm{p}<\right.$ 0.05), but not controls (Table 8).

Table 7. Effects of weekly and twice-weekly cleaning frequency on ecological properties of small mesocosms ${ }^{\mathrm{a}}$. Data given are

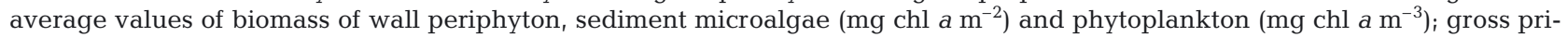
mary production (GPP; $\mathrm{g} \mathrm{O}_{2} \mathrm{~m}^{-3} \mathrm{~h}^{-1}$ ) of whole ecosystem, plankton and wall communities; and concentrations ( $\left.\mu \mathrm{M}\right)$ of dissolved inorganic nitrogen (DIN), phosphate $\left(\mathrm{PO}_{4}{ }^{3-}\right)$, and silica (dSi) sampled 1 to $2 \mathrm{wk}^{-1}$ over the experiment. Values are mean \pm SE of replicate $(\mathrm{n}=3)$ mesocosms. nd: not done, ${ }^{*} \mathrm{p}<0.01$

\begin{tabular}{|c|c|c|c|c|c|}
\hline Variable & Component & $\begin{array}{l}\text { Weekly } \\
\text { Control }\end{array}$ & Cleaned & $\begin{array}{l}\text { Twice-weekly } \\
\text { Control }\end{array}$ & Cleaned \\
\hline Biomass & $\begin{array}{l}\text { Wall periphyton } \\
\text { Phytoplankton } \\
\text { Sediment algae }\end{array}$ & $\begin{array}{l}1.6 \pm 0.5 \\
4.4 \pm 0.7 \\
\text { nd }\end{array}$ & $\begin{array}{l}1.0 \pm 0.1 \\
6.1 \pm 1.7 \\
\text { nd }\end{array}$ & $\begin{aligned} 3.0 & \pm 0.2^{*} \\
29.9 & \pm 2.5 \\
51.9 & \pm 8.8\end{aligned}$ & $\begin{aligned} 0.0 & \pm 0.0^{*} \\
35.2 & \pm 5.5 \\
85.1 & \pm 28.1\end{aligned}$ \\
\hline GPP & $\begin{array}{l}\text { Wall periphyton } \\
\quad \text { Plankton } \\
\text { Whole ecosystem }\end{array}$ & $\begin{array}{l}0.27 \pm 0.13 \\
0.11 \pm 0.07 \\
0.33 \pm 0.05\end{array}$ & $\begin{array}{l}0.19 \pm 0.12 \\
0.05 \pm 0.02 \\
0.32 \pm 0.04\end{array}$ & $\begin{array}{l}0.24 \pm 0.24 \\
0.14 \pm 0.06 \\
0.48 \pm 0.02\end{array}$ & $\begin{array}{l}0.02 \pm 0.07 \\
0.22 \pm 0.05 \\
0.42 \pm 0.02\end{array}$ \\
\hline Nutrient & $\begin{array}{l}\mathrm{DIN} \\
\mathrm{PO}_{4}{ }^{3-} \\
\mathrm{dSi}\end{array}$ & $\begin{array}{l}1.68 \pm 0.36 \\
0.05 \pm 0.01 \\
25.4 \pm 3.0\end{array}$ & $\begin{array}{l}2.63 \pm 0.38 \\
0.09 \pm 0.04 \\
31.1 \pm 8.6\end{array}$ & $\begin{array}{r}17.98 \pm 0.88 \\
0.78 \pm 0.03 \\
11.52 \pm 0.87\end{array}$ & $\begin{array}{r}23.41 \pm 2.48 \\
0.77 \pm 0.09 \\
14.54 \pm 2.61\end{array}$ \\
\hline
\end{tabular}


Table 8. Ecological properties of mesocosms of different size and shape (A to E, see Table 2) without and with wall-cleaning treatment (weekly) during successive summer experiments in $1994^{\mathrm{a}}$ and 1995, respectively. Data given are for average biomass of phytoplankton (sampled daily) and wall periphyton (sampled weekly), and for ecosystem gross primary production (GPP; sampled daily) over the course of experiments. Values are mean $\pm \mathrm{SE}$ of replicate $(\mathrm{n}=3)$ mesocosms. ${ }^{*} \mathrm{p}<0.05,{ }^{* *} \mathrm{p}<0.01$

\begin{tabular}{|c|c|c|c|c|}
\hline Tank & Treatment & $\begin{array}{l}\text { Algal biomass, } \\
\text { Wall periphyton }\end{array}$ & $\begin{array}{l}\mathrm{mg} \text { chl a m} \mathrm{m}^{-3} \\
\text { Phytoplankton }\end{array}$ & $\begin{array}{c}\text { Whole GPP } \\
\left(\mathrm{g} \mathrm{O}_{2} \mathrm{~m}^{-3} \mathrm{~h}^{-1}\right)\end{array}$ \\
\hline A & $\begin{array}{l}\text { Control } \\
\text { Cleaned }\end{array}$ & $\begin{aligned} 109.2 & \pm 16.9^{* *} \\
14.8 & \pm 7.0^{* *}\end{aligned}$ & $\begin{array}{l}5.5 \pm 0.3 \\
4.4 \pm 0.4\end{array}$ & $\begin{array}{l}0.32 \pm 0.01^{* *} \\
0.17 \pm 0.01^{* *}\end{array}$ \\
\hline B & $\begin{array}{l}\text { Control } \\
\text { Cleaned }\end{array}$ & $\begin{aligned} 73.5 & \pm 11.3^{* *} \\
7.6 & \pm 0.9^{* *}\end{aligned}$ & $\begin{array}{l}6.5 \pm 1.0 \\
6.1 \pm 1.7\end{array}$ & $\begin{array}{l}0.28 \pm 0.00 \\
0.32 \pm 0.04\end{array}$ \\
\hline $\mathrm{C}$ & $\begin{array}{l}\text { Control } \\
\text { Cleaned }\end{array}$ & $\begin{aligned} 43.0 & \pm 2.7^{* *} \\
7.7 & \pm 2.0^{* *}\end{aligned}$ & $\begin{array}{r}4.7 \pm 0.4^{* *} \\
10.7 \pm 0.8^{* *}\end{array}$ & $\begin{array}{l}0.26 \pm 0.00^{*} \\
0.24 \pm 0.01^{*}\end{array}$ \\
\hline $\mathrm{D}$ & $\begin{array}{l}\text { Control } \\
\text { Cleaned }\end{array}$ & $\begin{array}{r}51.4 \pm 5.1^{* *} \\
2.1 \pm 0.4^{* *}\end{array}$ & $\begin{array}{l}4.8 \pm 0.2^{*} \\
9.6 \pm 1.7^{*}\end{array}$ & $\begin{array}{l}0.17 \pm 0.01^{* *} \\
0.13 \pm 0.00^{* *}\end{array}$ \\
\hline E & $\begin{array}{l}\text { Control } \\
\text { Cleaned }\end{array}$ & $\begin{array}{r}20.6 \pm 3.1^{* *} \\
2.5 \pm 0.9^{* *}\end{array}$ & $\begin{array}{r}5.9 \pm 0.5^{* *} \\
10.2 \pm 0.5^{* *}\end{array}$ & $\begin{array}{l}0.22 \pm 0.01 \\
0.29 \pm 0.06\end{array}$ \\
\hline
\end{tabular}

imental realism and confound extrapolation of results to natural ecosystems (e.g. Dudzik et al. 1979, Harte et al. 1980). Whereas it is likely impossible to eliminate wall growth completely, several approaches have been suggested for minimizing the effects. These include: reducing duration of experiments (Harte et al. 1980), increasing container radius (Chen et al. 1997, 2000), periodic wall replacement (Dudzik et al. 1979, Lundgren 1985), and routine wall cleaning (e.g. Gamble et al. 1977, Kuiper 1984).

Physical cleaning of container walls, which is the most common approach employed for control of periphyton growth (e.g. Petersen et al. 1999), can be effective when done at a relatively high-frequency (Pilson et al. 1980). In the present study, we found that peri-
To consider further how mesocosm dimension may influence responses to wall-cleaning treatment, differences in algal biomass between treated systems and controls were calculated for each experimental ecosystem. In general, the decrease in periphytic biomass (control minus cleaned) was inversely related to container radius for both weekly and twice -weekly treatments (Fig. 6). These relationships were highly significant for weekly cleaning $\left(\mathrm{r}^{2}=0.52, \mathrm{p}<0.01\right.$, Fig. 6a) and marginally significant for twice-weekly treatment systems ( $\mathrm{r}^{2}=0.39, \mathrm{p}=0.07$, Fig. 6b). In addition, an inverse pattern was observed for phytoplankton biomass responses to treatment, where treatment induced an enhancement of phytoplankton that increased linearly from narrower to wider mesocosms $\left(r^{2}=0.67, p<\right.$ 0.01, Fig. 6b). Note that the absolute values for slopes of the respective increases in phytoplankton and decreases in periphyton biomass versus container radius were similar $(\approx 100)$, suggesting a direct connection between the 2 trends. Differences in sediment microalgal biomass in response to treatment were more closely related to mesocosm depth, with the largest differences in the shallow B tanks, followed by the $\mathrm{A}$ and then the $\mathrm{C}$ tanks.

\section{DISCUSSION}

\section{Treatment effects on periphyton growth}

Although mesocosms are valuable research tools for ecology studies (e.g. Beyers \& Odum 1993), periphytic growth on container walls may seriously reduce exper-

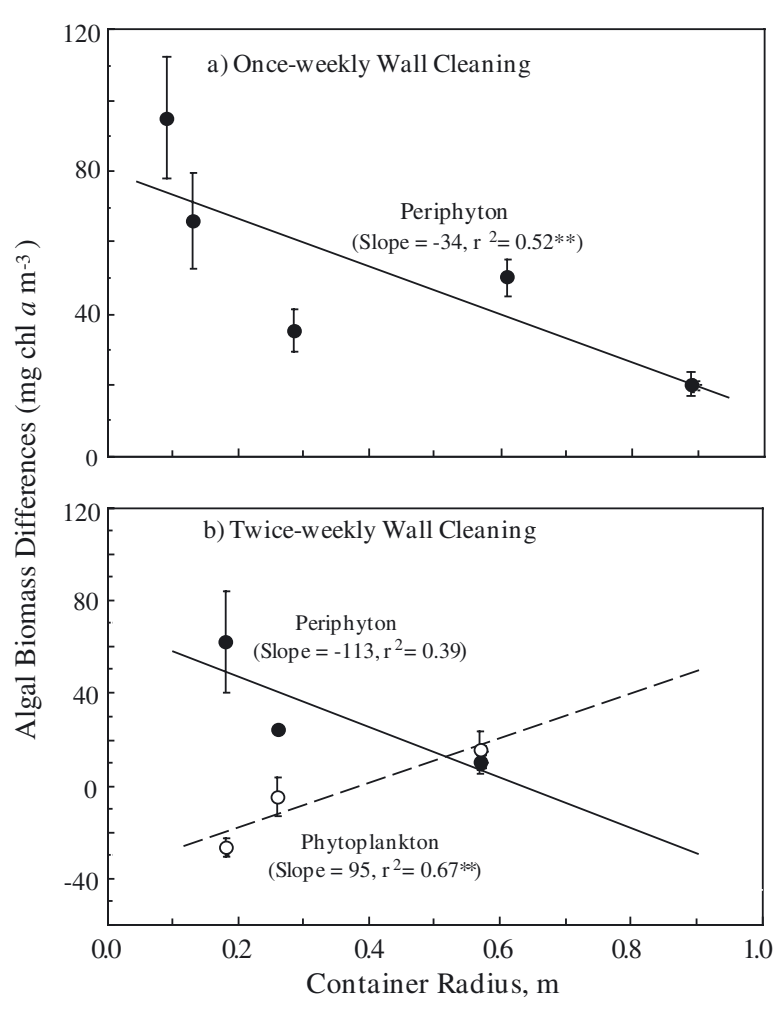

Fig. 6. Relationship between container radius and wall-cleaning induced differences in algal biomass (control-cleaned) for (a) wall periphyton with once-weekly wall-cleaning treatment, and (b) periphyton (filled symbols and solid lines) and phytoplankton (open symbols and dashed lines) with twiceweekly treatment. Slopes and $r^{2}$ values are given for linear regressions of radius and biomass differences for phytoplankton and wall periphyton. ${ }^{* *} \mathrm{p}<0.01$ 
phytic algae was effectively removed with twiceweekly treatment, but much less so with weekly wallcleaning (Table 7). Algal and bacterial cells, which tend to remain tightly bound to container walls and be resistant to physical removal (Dudzik et al. 1979), have high intrinsic growth rates that enable the periphyton community to rapidly re-establish biomass within days after scraping. In our mesocosms, periphyton dominated total algal biomass within a few days after weekly wall-cleaning, especially under nutrient-rich conditions with warm temperatures (Chen et al. 1997).

\section{Treatment effects on other algal assemblages}

Previous studies have demonstrated significant uptake of water column nutrients by periphyton growing either on hard substrates in nature (Cattaneo 1987 , Hansson 1990) or on mesocosm walls (Chen et al. 2000). The commonly observed decline of phytoplankton coinciding with rapid periphyton accumulation in aquatic mesocosms (Jassby et al. 1977, Rees 1979, Chen et al. 1997) may also reflect competition for nutrients. In this study, wall-cleaning generally resulted in increased phytoplankton biomass in the smaller A and B containers, particularly during the post-nutrient period when wall periphyton dominated (Fig. 1d,e). Nutrient concentrations in these experiments tended to be slightly higher in containers receiving wallcleaning treatments compared to untreated controls (Fig. 5), and this may have contributed to the increased abundance of planktonic algae. In addition, diatoms dislodged (with cleaning) from container walls may represent 'recruits' to the planktonic assemblages, which were also dominated by diatoms (Fig. 3).

For the larger $\mathrm{C}$ tanks, a surprising inverse pattern was observed, where wall-cleaning treatment resulted in lower phytoplankton biomass (Fig. 1f). We can only speculate on the explanation for this counter-intuitive observation. Evidence from previous studies using these experimental systems (Chen et al. 1997) suggests that herbivorous zooplankton (copepods) tend to congregate near container walls and feed on periphyton biomass. The impact of this grazing was generally more pronounced for narrower systems (Chen et al. 2000), being inversely related to container radius (ranging from 0.2 to $1.8 \mathrm{~m}$ ). In intermediate width containers (e.g. our $0.6 \mathrm{~m}$ radius $\mathrm{C}$ tanks), it is likely that zooplankton tend to redirect their grazing pressure to phytoplankton when wall periphyton are dislodged from walls. This might explain the reduced phytoplankton abundance observed with wall-cleaning in $\mathrm{C}$ tanks (Fig. 1f).

The mean biomass of sediment microalgae was significantly higher in the cleaned systems than in the controls for smaller (A and B) containers, although differences were confined to the batch and post-nutrient periods for the A tanks (Fig. 1g,h). Rates of sediment GPP were, however, not significantly enhanced with wall-cleaning suggesting this response may be attributable more to recruitment of dislodged periphytic diatoms to the sediment habitat rather than to nutrientenhanced algal growth. Indeed, sediment microalgae do not always respond to nutrient addition to overlying waters (Blumenshine et al. 1997), because cell growth depends more on nutrients diffusing from underlying sediment (e.g. Granéli \& Sundbäck 1985). The mean values for both biomass and GPP for sediment microalgae in the larger $\mathrm{C}$ tanks declined markedly (although not significantly) with wall-cleaning treatment. A possible mechanism, analogous to that suggested for phytoplankton responses in the $\mathrm{C}$ systems, would involve increased abundance of insects and other motile epibenthic herbivores (Table 6) shifting their predominant food source from periphyton to sediment microalgae. Overall, however, sediment microalgal growth in these mesocosms appears to have been more directly related to light availability. The significant linear relationship evident between mean sediment microalgal biomass and bottom light intensity is consistent with numerous field observations (e.g. Pinckney \& Zingmark 1993a).

Taxonomic composition of phytoplankton was also affected by wall-cleaning in the post-nutrient period (Fig. 3). Although phytoplankton was dominated by diatoms in both control and treated systems, a greater taxonomic richness was found in the cleaned systems (Fig. 3). Previous studies in these systems indicate that wall periphyton tend to regulate both nutrient concentrations and the N/P ratio in the water column (Chen et al. 2000). Since the composition of algal assemblages tends to vary with the N/P ratio (Tilman et al. 1982), this suggests a mechanism by which wall periphyton regulate phytoplankton community competition.

\section{Other community responses to treatment}

Not only did wall-cleaning affect biomass and taxonomic composition of planktonic algal assemblages, but it apparently also enhanced growth of bacterioplankton under nutrient rich conditions following the nutrient pulse (Table 5). Although abundances of planktonic bacteria tend to be regulated by grazing activity and/or substrate availability (e.g. Sanders et al. 1992), frequent reports of significant correlations between bacterioplankton and phytoplankton abundances (e.g. Azam et al. 1983, Cole et al. 1988, Shiah \& Ducklow 1995) underscore the tendency for substrate limitation to dominate. The relatively high abundances 
of bacterioplankton in our experimental systems compared to those observed in the Chesapeake Bay (Shiah 1993, Sanford et al. 2001) indicate that predation rates may be relatively low in these mesocosms. In the present study, bacterioplankton abundances generally followed phytoplankton chl $a$ trends. Both were relatively constant and unaffected by wall-cleaning during initial periods of the experiment; however, both exhibited marked increases in response to nutrient additions, particularly in systems with wall-cleaning (Fig. 1d-f, Table 5).

Among the numerous factors typically cited as regulating growth of benthic macrofauna, food availability is of primary importance (Smetacek 1984, Rasmussen \& Kalff 1987, Widbom \& Elmgren 1988). Phytoplankton deposition from the overlying water column and related pelagic-benthic interactions represent the major food sources for deposit-feeding benthos in coastal environments (Grassle et al. 1985, Rasmussen \& Kalff 1987). Animals dominating the experimental macrofauna in this study were all deposit-feeders (Table 6; Day et al. 1989). Indeed, in the present experiment sediment chl a levels were significantly increased with wall-cleaning (Figs. 1g-i \& 2), indicating elevated food supplies for benthic deposit-feeding macrofauna (e.g. Reise 1992). Whereas significantly higher phytoplankton biomass was evident in wallcleaning systems, increases occurred several days after nutrient additions (Fig. 1d-f). Increased sediment $\mathrm{chl} a$ levels associated with wall-cleaning may be attributable more to dislodged periphytic algal cells than to sinking phytoplankton or to in situ growth. Mean macrofaunal biomass levels were consistently higher (by 30 to $260 \%$ ) in the cleaned systems than in the controls for all 3 mesocosm types. Due to high variability among replicate systems, however, differences were significant only in the larger C systems (Table 6).

\section{Periphyton effects on ecosystem-level properties}

Even though control experimental ecosystems were dominated by their periphytic communities, values for total algal biomass and ecosystem GPP were relatively independent of wall-cleaning treatment and mesocosm dimension (Figs. 1, 2 \& 4). Evidently, a compensatory balance between periphyton and other algal assemblages (viz. phytoplankton and sediment microalgae) exists through their competition for limited supplies of light and nutrients (e.g. Lewis \& Platt 1982). Conversely, however, these counteracting shifts in algal abundance suggest that the development of phytoplankton and sediment microalgae may be inhibited by the growth of wall periphyton. This was the case in our experiments, where relative contributions of the $3 \mathrm{dom}$ - inant habitats (planktonic, periphytic, benthic) to ecosystem primary production and total algal biomass varied significantly between the control and cleaned systems (Figs. 1, 2 \& 4). These results indicate that wallcleaning may be less important for experiments in which total ecosystem properties are of primary interest than for studies focusing on the dynamics of organisms or processes within a particular habitat.

Whereas previous studies have found that aspects of nutrient cycling are significantly altered by growth of periphytic communities in experimental ecosystems (Confer 1972, Eppley et al. 1978, Harte et al. 1980, Blumenshine et al. 1997, Chen et al. 2000), the results of the present study suggest that effects tend to be muted at the ecosystem level. We found that nutrient concentrations were slightly lower (by 0 to $20 \%$ ) in some control systems; however, differences between control and treated mesocosms were generally not significant (Fig. 5, Table 7). Significant increases in nutrient concentrations with wall-cleaning were evident only in C tanks following the nutrient pulse (Fig. 5). Apparently, demand for nutrients remained relatively unaffected by wall-cleaning because of compensatory increases in phytoplankton and sediment microalgae accompanying removal of wall periphyton (Chen et al. 2000). As a consequence, wall-cleaning did not substantially disrupt the overall nutrient balance in these experimental systems.

Although we chose to retain scraped periphyton within treated experimental ecosystems in this study, we can compute the potential impact that periphyton removal from containers would have had on system nitrogen budgets. The difference between periphytic chl $a$ levels in treated and control systems ranged from approximately 10 to $60 \mathrm{mg} \mathrm{chl} \mathrm{a} \mathrm{m}{ }^{-3}$ and 20 to $100 \mathrm{mg}$ chl $a \mathrm{~m}^{-3}$ for twice-weekly and once-weekly treatments, respectively (Fig. 6). Assuming an average carbon/chl-a ratio of 75 (J. E. Petersen et al. unpubl. data) and Redfield stoichiometry, the equivalent $\mathrm{N}$ removed from walls ranged from approximately 10 to $100 \mu \mathrm{mol}$ $\mathrm{I}^{-1}$, which would be equivalent to $\mathrm{N}$ removal rates of 3 to $30 \mu \mathrm{mol} \mathrm{l}^{-1} \mathrm{~d}^{-1}$. These rates can be compared to the equivalent $\mathrm{N}$ uptake associated with the GPP of the experimental ecosystems (Fig. 4). Assuming a photosynthetic quotient of 1.25 and Redfield stoichiometry, we estimated a GPP N-demand of 10 to $30 \mu \mathrm{mol} \mathrm{l}^{-1} \mathrm{~d}^{-1}$, suggesting that removal of periphyton from the containers would have had an enormous impact on the productivity of these experimental ecosystems.

\section{Scaling responses to container dimensions}

As observed in previous studies (Chen et al. 1997), the relative contribution of wall periphyton to total 
algal biomass was inversely related to mesocosm radius (Fig. 2). Hence, effects of wall periphyton on processes such as nutrient cycling would have also tended to decrease with container radius. On the other hand, biomass of sediment microalgae in these experimental systems was significantly related to bottom light intensity, which in turn is generally related to water depth (e.g. Kirk 1994). Similar positive relationships between microphytobenthic biomass and light at the sediment surface have been reported for many natural coastal systems (e.g. Sundbäck \& Granéli 1988, Pinckney \& Zingmark 1993b). In experimental ecosystems such as those in this study, however, light at the sediment-water interface may also depend on container radius, because of the attenuation associated with container walls (e.g. Chen et al. 2000). Similarly, phytoplankton biomass was also directly related to container radius in control mesocosms (Fig. 2), and this relationship may derive, in part, from indirect effects of competition between phytoplankton and wall periphyton for limited nutrient pools (Chen et al. 2000).

As a consequence of the strong effects of container radius on periphyton growth in this study, responses to wall-cleaning treatment also varied with the radius of the experimental systems. In fact, the difference in periphytic algal biomass between the cleaned and control systems (control minus treated) decreased linearly with mesocosm radius (Fig. 6), where larger differences indicate more periphyton removed. The slope of this relationship was greater (i.e. stronger scaling effect) for systems receiving twice-weekly treatment. We found a positive linear relationship between container radius and biomass differences for phytoplankton (Fig. 6b). This trend is consistent with the idea of competitive balance among algal groups vying for the same limited resources, where increased phytoplankton growth 'compensates' for periphyton loss due to cleaning. The similarity in the absolute values for slopes of periphyton decrease and phytoplankton increase with radius (Fig. 6b) suggests that much of the reduction in periphyton biomass with wall-cleaning could be explained by a comparable increase in phytoplankton. Sediment microalgae showed no such relationship between container radius and the biomass differences with cleaning treatment. Differences in sediment microalgal biomass between treatments and controls were, however, substantially larger in the shallower (0.5 m depth) B tanks compared to the deeper (1 $\mathrm{m}$ depth) A and C systems, suggesting a stronger scaling response to system depth.

In summary, our observations reveal that routine removal of periphyton from the walls of experimental systems results in significant changes in the structure and partitioning of biomass among wall, plankton, and sediment habitats. Ecosystem-level properties, includ- ing primary production, total algal biomass and nutrient concentrations are, however, generally unaffected by wall-cleaning. Whereas twice-weekly removal of materials from container walls efficiently controlled periphyton growth, weekly cleaning was much less effective. The relative impact of wall-cleaning on periphyton and phytoplankton biomass scaled consistently to the radius of experimental containers. Although periphyton scraped from container walls was not removed from the experimental systems in this study, simple calculations indicate that doing so would have resulted in disruption of system nutrient balances. Thus, we conclude that while growth of periphyton on walls is an artifact inherent to experimental ecosystems, effects are generally confined to properties related to specific habitats (e.g. planktonic, benthic) rather than those pertaining to the integrated ecosystem. These effects can be minimized with frequent $(>2$ $\mathrm{wk}^{-1}$ ) routine cleaning, as well as retention of periphytic material within the experimental system and use of relatively wide ( $>1 \mathrm{~m}$ diam.) containers.

Acknowledgements. This work was supported by a grant from the U.S. Environmental Protection Agency as part of the Multiscale Experiment Ecosystem Research Center (MEERC) at the University of Maryland Center for Environmental Science (Grant no. R819640). We are indebted to Teresa Coley, Jeff Cornwell, Debbie Hinkle, Chris Madden, John Petersen, John Posy and Tom Wazniak, who provided assistance with sampling and analyses as well as valuable discussions during the course of this research. We are also acknowledge the helpful comments of 3 anonymous reviewers. We thank L. Van Heukelem for helping with pigment analyses using HPLC and for valuable suggestions in data interpretation. Benthic macrofauna were analyzed by Cove Corporation (Lusby, MD). We gratefully acknowledge John Petersen for access to unpublished literature review data, Mike Roman for use of zooplankton data, and Elgin Perry for statistical advice.

\section{LITERATURE CITED}

Azam F, Fenchel T, Field JG, Gray JS, Meyer-Reil LA, Thingstad F (1983) The ecological role of water-column microbes in the sea. Mar Ecol Prog Ser 10:257-263

Barlow RG, Mantoura RFC, Peinert RD, Miller AEJ, Fileman TW (1995) Distribution, sedimentation and fate of pigment biomarkers following thermal stratification in the western Alboran Sea. Mar Ecol Prog Ser 125:279-291

Beyers RJ, Odum HT (1993) Ecological microcosms. SpringerVerlag, New York

Bidigare RR, Frank TJ, Zastrow C, Brooks JM (1986) The distribution of algal chlorophylls and their degradation products in the Southern Ocean. Deep Sea Res 33:923-937

Bjørnland J, Tangen J (1979) Pigmentation and morphology of a marine Gyrodinium (Dinophyceae) with a major cartenoid different from peridinin and fucoxanthin. J Phycol 15:457-463

Blumenshine SC, Vadeboncoeur Y, Lodge DM, Cottingham KL, Knight SE (1997) Benthic-pelagic links: responses of benthos to water-column nutrient enrichment. J North Am 
Benthol Soc 16: 466-479

Burkholder JM, Mason KM, Glasgow HB Jr (1992) Water-column nitrate enrichment promotes decline of eelgrass Zostera marina: evidence from seasonal mesocosm experiments. Mar Ecol Prog Ser 81:163-178

Carritt DE, Carpenter JH (1966) Comparison and evaluation of currently employed modifications of the Winkler method for determining dissolved oxygen in seawater; a NASCO report. J Mar Res 24:286-318

Cattaneo A (1987) Periphyton in lakes of different trophy. Can J Fish Aquat Sci 44:296-303

Chen CC (1998) Wall effects in estuarine mesocosms: scaling experiments and simulation model. $\mathrm{PhD}$ thesis, University of Maryland, College Park

Chen CC, Petersen JE, Kemp WM (1997) Spatial and temporal scaling of periphyton growth on walls of estuarine mesocosms. Mar Ecol Prog Ser 155:1-15

Chen CC, Petersen JE, Kemp WM (2000) Nutrient uptake in experimental estuarine ecosystems: scaling and partitioning rates. Mar Ecol Prog Ser 200:103-116

Cole JJ, Findlay S, Pace ML (1988) Bacterial production in fresh and saltwater ecosystems: a cross-system overview. Mar Ecol Prog Ser 43:1-10

Confer JL (1972) Interrelations among plankton, attached algae, and the phosphorus cycle in artificial open systems. Ecol Monogr 42:1-23

Crowder MJ, Hand DJ (1990) Analysis of repeated measures. Chapman \& Hall, London

Day JW, Hall CAS, Kemp WM, Yanez-Arancibia A (1989) Estuarine ecology, 1st edn. John Wiley, New York

de Lafontaine Y, Leggett WC (1987) Effect of container size on estimates of mortality and predation rates in experiments with macrozooplankton and larval fish. Can J Fish Aquat Sci 44:1534-1543

Doering PH, Oviatt CA (1986) Application of filtration rate models to field populations of bivalves: an assessment using experimental mesocosms. Mar Ecol Prog Ser 31:265-275

Dudzik M, Harte J, Jassby A, Lapan E, Levy D, Rees J (1979) Some considerations in the design of aquatic microcosms for plankton research. Int J Environ Stud 13:125-130

Edmondson WT (1955) Factors affecting productivity in fertilized salt water. Deep Sea Res 3:451-464

Eppley RW, Koeller P, Wallace GT (1978) Stirring influences the phytoplankton species composition within enclosed columns of coastal sea water. J Exp Mar Biol Ecol 32:219-239

Gamble JC, Davies JM, Steele JH (1977) Loch Ewe bag experiment, 1974. Bull Mar Sci 27:146-175

Giesy JP (ed) (1980) Microcosms in ecological research. DOE Symposium Series 52, Conf-781101, Nat Tech Inform Serv, Springfield, VA

Goldsborough WJ, Kemp WM (1988) Light responses of a submersed macrophyte: implications for survival in turbid tidal waters. Ecology 69:1775-1786

Granéli E, Sundbäck K (1985) The response of planktonic and microbenthic algal assemblages to nutrient enrichment in shallow coastal water, southwest Sweden. J Exp Mar Biol Ecol 85:253-268

Grassle JF, Grassle JP, Brown-Leger LS, Petrecca RF, Copley NJ (1985) Subtidal macrobenthos of Narragansett Bay: field and mesocosm studies of the effects of organic input on benthic populations. In: Gray JS, Christiansen ME (eds) Marine biology of polar regions and effects of stress on marine organisms. John Wiley, New York, p 421-434

Grice D, Reeve MR (eds) (1982) Marine mesocosms. SpringerVerlag, New York
Grice GD, Harris RP, Reeve MR, Heinbokel JF, Davis CO (1980) Large-scale enclosed water-column ecosystems: An overview of foodweb I, the final CEPEX experiment. J Mar Biol Assoc UK 60:401-414

Hansson LA (1990) Quantifying the impact of periphytic algae on nutrient availability for phytoplankton. Fresh Biol 24:265-273

Harte J, Levy D, Rees J, Saegebarth E (1980) Making microcosms an effective assessment tool. In: Giesy JP (ed) Microcosms in ecological research. Nat Techn Inform Serv, Springfield, VA, p 105-137

Heinle DR, Flemer DA, Huff RT, Sulkin ST, Ulanowicz RE (1979) Effects of perturbations on estuarine microcosms. In: Dame RF (ed) Marsh-estuarine systems simulation. University of South Carolina Press, Columbia, SC, p 119-141

Hobbie JE, Daley RJ, Jasper S (1977) Use of nuclepore filters for counting bacteria by fluorescence microscopy. Appl Environ Microbiol 33:1225-1228

Hooks CE, Bidigare RR, Keller MD, Guilard RL (1988) Coccoid eukaryotic marine ultraplankters with four different HPLC pigment signatures. J Phycol 24:571-580

Jassby A, Dudzik M, Rees J, Lapan E, Levy D, Harte J (1977) Production cycles in aquatic microcosms. Rep no. EPA600/7-77-097, Environmental Protection Agency, Washington, DC

Johnsen G, Sakshaug E (1993) Bio-optical characteristics and photoadaptive responses in the toxic and bloom-forming dinoflagellates Gyrodinium aureolum, Gymnodinium galatheanum, and two strains of Prorocentrum minimum. J Phycol 29:627-642

Kelly JR, Berounsky VM, Nixon SW, Oviatt CA (1985) Benthic-pelagic coupling and nutrient cycling across an experimental eutrophication gradient. Mar Ecol Prog Ser 26:207-219

Kirk JTO (1994) Light and photosynthesis in aquatic ecosystems. Cambridge University Press, New York

Kuiper J (1981) Fate and effects of mercury in marine plankton communities in experimental enclosures. Ecotoxicol Environ Saf 5:106-134

Kuiper J (1984) Marine ecotoxicological test: multispecies and model ecosystem experiments. In: Persoone G, Jaspers E, Claus C (eds) Ecotoxicological testing for the marine environment. State Univ Ghent and Inst Mar Sci Res, Bredene, Belgium, p 527-588

Kuuppo-Leinikki P, Autio R, Hällfors S, Kuosa H, Kuparinen J, Pajuniemi R (1994) Trophic interactions and carbon flow between picoplankton and protozoa in pelagic enclosures manipulated with nutrients and a top predator. Mar Ecol Prog Ser 107:89-102

Lalli CM (1990) Enclosed experimental marine ecosystems: a review and recommendations. Springer-Verlag, New York

Letelier RM, Bidigare RR, Hebel DV, Ondrusek M, Winn CD, Karl DM (1993) Temporal variability of phytoplankton community structure based on pigment analysis. Limnol Oceanogr 38:1420-1437

Levin LA (1986) Effects of enrichment on reproduction in the opportunistic polychaete Streblospio benedicti (Webster): a mesocosm study. Biol Bull 171:143-160

Lewis MR, Platt T (1982) Scales of variability in estuarine ecosystems. In: Kennedy VS (ed) Estuarine comparisons. Academic Press, New York, p 3-20

Lundgren A (1985) Model ecosystems as a tool in freshwater and marine research. Arch Hydrobiol Suppl 70:157-196

Millie DF, Paerl HW, Hurley JP (1993) Microalgal pigment assessments using high-performance liquid chromatography: a synopsis of organismal and ecological applications. 
Can J Fish Aquat Sci 50:2513-2527

Neundorfer JV, Kemp WM (1993) Nitrogen versus phosphorus enrichment of brackish waters: responses of the submersed plant Potamogeton perfoliatus and its associated algal community. Mar Ecol Prog Ser 94:71-82

Odum HT (1956) Primary production in flowing water. Limnol Oceanogr 1:102-117

Oviatt CA, Pilson MEQ, Nixon SW, Frithsen JB, Rudnick DT, Kelly JR, Grassle JF, Grassle JP (1984) Recovery of a polluted estuarine system: a mesocosm experiment. Mar Ecol Prog Ser 16:203-217

Oviatt CA, Keller AA, Sampou PA, Beatty LL (1986) Patterns of productivity during eutrophication: a mesocosm experiment. Mar Ecol Prog Ser 28:69-80

Oviatt C, Doering P, Nowicki B, Reed L, Cole J, Frithsen J (1995) An ecosystem level experiment on nutrient limitation in temperate coastal marine environments. Mar Ecol Prog Ser 116:171-179

Painting SJ, Lucas MI, Muir DG (1989) Fluctuations in heterotrophic bacterial community structure, activity and production in response to development and decay of phytoplankton in a microcosm. Mar Ecol Prog Ser 53:129-141

Parsons TR, Maita Y, Lalli CM (1984) A manual of chemical and biological methods for seawater analysis. Pergamon Press, New York

Perez KT, Morrison GE, Davey EW, Lackie NF, Soper AE, Blasco RJ, Winslow DL (1991) Influence of size on fate and ecological effects of kepone in physical models. Ecol Appl $1: 237-248$

Perez KT, Morrison GM, Lackie NF, Oviatt CA, Nixon SW, Buckley BA, Heltshe JF (1977) The importance of physical and biotic scaling to the experimental simulation of a coastal marine ecosystem. Helgo Wiss Meeresunters 30:144-162

Petersen JE, Chen CC (1999) A method for measuring depthintegrated community metabolism in experimental planktonic-benthic ecosystems. Hydrobiologia 391:23-32

Petersen JE, Chen CC, Kemp WM (1997) Scaling aquatic primary productivity: experiments under nutrient- and lightlimited conditions. Ecology 78:2326-2338

Petersen JE, Cornwell J, Kemp WM (1999) Implicit scaling in the designed of enclosed ecosystems. Oikos 85:3-18

Pilson MEQ, Oviatt CA, Nixon SW (1980) Annual nutrient cycles in marine microcosm. In: Giesy JP (ed) Microcosms in ecological research. Nat Techn Inform Serv, Springfield, VA, p 753-778

Pinckney J, Zingmark RG (1993a) Photophysiological responses of intertidal benthic microalgal communities to in situ light environments: Methodological considerations. Limnol Oceanogr 38:1373-1383

Pinckney JL, Zingmark RG (1993b) Modeling the annual production of intertidal benthic microalgae in estuarine ecosystems. J Phycol 29:396-407

Rasmussen JB, Kalff J (1987) Empirical models for zoobenthic biomass in lakes. Can J Fish Aquat Sci 44:990-1001

Raymont JEG, Miller RS (1962) Production of marine zooplankton with fertilization in an enclosed body of sea

Editorial responsibility: Jennifer Purcell (Contributing

Editor), Anacortes, Washington, USA water. Int Rev Gesamten Hydrobiol 47:169-209

Rees JT (1979) Community development in freshwater microcosms. Hydrobiologia 63:113-128

Reise K (1992) Grazing on sediment shores. In: John DM, Hawkins SJ, Price JH (eds) Plant-animal interactions in the marine benthos. Clarendon Press, Oxford, p 133-145

Ringelberg J, Kersting K (1978) Properties of an aquatic micro-ecosystem: I. General introduction to the prototypes. Arch Hydrobiol 83:47-68

Rudnick DT, Oviatt CA (1986) Seasonal lags between organic carbon deposition and mineralization in marine sediments. J Mar Res 44:815-837

Sampou P, Oviatt CA (1991) Seasonal patterns of sedimentary carbon and anaerobic respiration along a simulated eutrophication gradient. Mar Ecol Prog Ser 72:271-282

Sanders RW, Caron DA, Berninger U-G (1992) Relationships between bacteria and heterotrophic nanoplankton in marine and fresh waters: an inter-ecosystem comparison. Mar Ecol Prog Ser 86:1-14

Sanford LP (1997) Turbulent mixing in experimental ecosystem studies. Mar Ecol Prog Ser 161:265-293

Sanford A, Morgan J, Evans D, Ducklow H (2001) Bacterioplankton dynamics in estuarine mesocosms: Effects of tank shape and size. Microb Ecol 41:45-55

Shiah FK (1993) Multi-scale variability of bacterioplankton abundance, production and growth rate in the temperate estuarine ecosystems. PhD thesis, University of Maryland

Shiah FK, Ducklow HW (1995) Regulation of bacterial abundance and production by substrate supply and bacterivory: a mesocosm study. Microb Ecol 30:239-255

Smetacek V (1984) The supply of food to the benthos. In: Fasham MJ (ed) Flows of energy and materials in marine ecosystems, theory and practice. Plenum Press, New York, p 733

Sundbäck K, Granéli W (1988) Influence of microphytobenthos on the nutrient flux between sediment and water: a laboratory study. Mar Ecol Prog Ser 43:63-69

Threlkeld ST (1994) Benthic-pelagic interactions in shallow water columns: an experimentalist's perspective. Hydrobiologia 275/276:293-300

Threlkeld ST, Drenner RW (1987) An experimental mesocosm study of residual and contemporary effects of an omnivorous filter-feeding, clupeid fish on plankton community structure. Limnol Oceanogr 32:1331-1341

Tilman D, Kilham SS, Kilham P (1982) Phytoplankton community ecology: The role of limiting nutrients. Annu Rev Ecol Syst 13:349-372

Van Heukelem L, Lewitus AJ, Kana TM, Craft NE (1994) Improved separations of phytoplankton pigments using temperature-controlled high performance liquid chromatography. Mar Ecol Prog Ser 114:303-313

Whitney DE, Darley WM (1979) A method for the determination of chlorophyll $a$ in samples containing degradation products. Limnol Oceanogr 24:183-186

Widbom B, Elmgren R (1988) Response of benthic meiofauna to nutrient enrichment of experimental marine ecosystems. Mar Ecol Prog Ser 42:257-268

Submitted: May 23, 2003; Accepted: February 2, 2004

Proofs received from author(s): April 19, 2004 